\title{
PENGARUH ROA, ROE DAN EPS TERHADAP HARGA SAHAM PERUSAHAAN PERBANKAN TERDAFTAR DI BEI PERIODE 2016-2019
}

\author{
Oleh : Dian Indah Sari \\ dianindahsari1977@gmail.com \\ (Program Studi Sistem Informasi, Universitas Bina Sarana Informatika)
}

\begin{abstract}
Abstrak-Penelitian ini bertujuan untuk mengetahui pengaruh ROA, ROE dan EPS terhadap harga saham perusahaan perbankan yang terdaftar di Bursa Efek Indonesia periode 2016-2019. Teknik analisis penelitian ini adalah teknik analisis kuantitatif. Alat analisis data penelitian adalah uji asumsi klasik dan analisis regresi linier berganda. Data penelitian diperoleh melalui laporan keuangan (Neraca dan Laporan Laba Rugi) perusahaan perbankan yang terdaftar di Bursa Efek Indonesia untuk periode 2016-2019. Kesimpulannya dapat ditarik sebagai berikut: Variabel ROA memiliki pengaruh positif dan signifikan terhadap variabel harga saham perusahaan perbankan pada periode 2016-2019. Variabel ROE memiliki pengaruh positif dan signifikan terhadap variabel harga saham perusahaan perbankan periode 2016-2019. Variabel EPS memiliki pengaruh positif dan signifikan terhadap variabel harga saham perusahaan perbankan pada periode 2016-2019. Variabel ROA, ROE dan EPS memiliki pengaruh positif dan signifikan terhadap variabel harga saham perusahaan perbankan pada periode 2016-2019.
\end{abstract}

Kata Kunci : ROA, ROE, EPS, Harga Saham

\begin{abstract}
This study aims to determine the effect of ROA, ROE and EPS on the stock prices of banking companies listed on the Indonesia Stock Exchange Period 2016-2019. Analysis technique This research is a quantitative analysis technique. The research data analysis tool is a classic assumption test and multiple linear regression analysis. The research data was obtained through financial statements (Balance Sheet and Income Statement) of banking companies listed on the Indonesia Stock Exchange for the period of 2016-2019. The conclusion can be drawn as follows: Variable ROA has a positive and significant effect on the variable Stock Price of banking companies in the period 2016-2019. ROE variable has a positive and significant effect on the stock price of banking companies 2016-2019 period. The EPS variable has a positive and significant effect on the share price variable of banking companies in the 2016-2019 period. Variable ROA, ROE and EPS have a positive and significant influence on the variable price of shares of banking companies in the period of 2016-2019. Further researchers are advised to increase the number of samples, increase financial ratios and look for other variables that affect stock prices.
\end{abstract}

Keywords : ROA, ROE, EPS, Stock Price 


\section{PENDAHULUAN}

Industri perbankan menghadapi tantangan di semua aspek bisnis.Tantangan yang dihadapi oleh industri perbankan mencapai semua basis bisnis mulai dari bisnis utama yaitu menyalurkan pinjaman dan bisnis kedua yaitu payment. Ancaman yang dihadapi oleh Bisnis bank terjadi peningkatan terutama kinerja bisnis bank karena lambatnya pertumbuhan ekonomi dan sektor potensial bagi bisnis bank.

Sektor utama dari Industri perbankan yaitu sektor industri pengolahan mengalami perkembangan semakin melambat. sektor industri pengolahan memberikan kontribusi untuk pertumbuhan ekonomi Indonesia berada dibawah 20\%. Kontribusi sektor industri pengolahan sekitar 15 tahun lalu berada diatas $25 \%$. Hal ini menunjukkan bahwa industri perbankan memiliki pangsa pasar semakin kecil.

Dapat disimpulkan bahwa tantangan yang dihadapi oleh lembaga perbankan ada dua. Tantangan pertama yaitu persaingan semakin meningkat dengan banyaknya shadow banking. Tantangan kedua yaitu potensi pasar dimiliki industri perbankan semakin kecil. Tahun 2020 industri perbankan harus dapat mempertahankan eksistensi sebagai lembaga intermediasi.

ROA menggambarkan kemampuan perusahaan memperoleh laba dengan memanfaatkan aktiva. ROA merupakan ukuran efektivitas manajemen dalam mengelola investasinya. Semakin besar rasio ROA maka semakin baik dan sebaliknya. ROA digunakan untuk mengukur tingkat pengembalian investasi yang dilakukan perusahaan dengan menggunakan seluruh aktiva yang dimiliki. Semakin tinggi nilai ROA menunjukkan semakin baik dalam memberikan pengembalian kepada penanam modal. Semakin tinggi nilai ROA menandakan bahwa perusahaan tersebut mengalami keuntungan. Apabila nilai ROA cenderung menurun bahwa perusahaan mengalami penurunan laba atau mengalami kerugian.

ROE menggambarkan kemampuan perusahaan dalam menghasilkan laba berdasarkan saham tertentu. ROE salah satu indikator profitabilitas paling penting. Semakin tinggi nilai ROE perusahaan maka semakin baik kinerjanya dalam menghasilkan laba bersih setelah pajak. ROE semakin tinggi mengindikasikan posisi keuangan perusahaan semakin kuat dan sebaliknya.

EPS menggambarkan besarnya keuntungan yang diperoleh dari setiap lembar saham. EPS komponen penting pertama dalam melakukan analisis perusahaan. EPS salah satu indikator kesuksesan dari kinerja perusahaan. Semakin tinggi EPS yang diberikan kepada para investor maka menunjukan bahwa perusahaan 
mampu memberikan tingkat kesejahteraan yang tinggi. Semakin rendah EPS yang diberikan kepada Investor menunjukkan bahwa perusahaan memberikan tingkat kesejahteraan yang semakin rendah.

Penelitian sebelumnya (Ani, Sari \& Cipta, 2019) yang meneliti tentang pengaruh ROA, ROE \& EPS terhadap harga saham menyimpulkan bahwa ROA dan ROE secara parsial berpengaruh positif dan signifikan terhadap harga saham sedangkan EPS secara parsial berpengaruh positif dan tidak signifikan terhadap harga saham sektor Farmasi yang terdaftar di BEI. Hasil penelitian oleh (Egam, Ilat \& Pangerapan, 2017) memberikan kesimpulan bahwa ROA dan ROE tidak memiliki pengaruh terhadap harga saham sedangkan EPS memiliki pengaruh signifkan terhadap harga saham yang terdaftar di indeks LQ45 tahun 2013-2015.

Penelitian yang dilakukan oleh (Fadila \& Saifi, 2018) menyimpulkan bahwa EPS dan ROE mempunyai pengaruh signifikan secara simultan terhadap harga penutupan saham perusahaan perbankan di BEI tahun 2014-2016. Hasil Penelitian yang dilakukan oleh (Triawan \& Shofawati, 2017) menyimpulkan bahwa ROA dan ROE tidak memiliki pengaruh yang signifikan terhadap harga saham, hanya EPS yang memiliki pengaruh signifikan terhadap harga saham perusahaan di Jakarta Islam Index periode 2011-2015.

Dari hasil penelitian dari beberapa peneliti diatas menghasilkan kesimpulan penelitian yang berbeda. Berdasarkan perbedaan hasil penelitian dari beberapa peneliti maka penulis melakukan penelitian yang bertujuan untuk mengetahui pengaruh ROA, ROE dan PER terhadap Harga Saham perusahaan Perbankan yang terdaftar di BEI Periode 2016-2019.

Analisa Rasio merupakan alat analisis yang digunakan untuk menganalisis laporan keuangan perusahaan sehingga dapat diketahui kekuatan dan kelemahan suatu perusahaan menurut (Munawir, 2014).

Rasio Profitabilitas merupakan rasio yang digunakan untuk menilai kemampuan perusahaan dalam mencari keuntungan menurut (Kasmir, 2012).

Manfaat rasio profitabilitas menurut (Kasmir, 2012) antara lain:

1. Mengetahui besarnya tingkat laba perusahaan yang diperoleh dalam satu periode (Kasmir, 2012).

2. Mengetahui posisi laba perusahaan tahun sebelumnya dengan tahun sekarang (Kasmir, 2012).

3. Mengetahui perkembangan laba dari waktu ke waktu (Kasmir, 2012).

4. Mengetahui besarnya laba bersih sesudah pajak dengan modal sendiri (Kasmir, 2012). 
5. Mengetahui produktivitas dari seluruh dana perusahaan yang digunakan (Kasmir, 2012).

ROA adalah rasio yang menggambarkan sejauh mana kemampuan asset-asset yang dimiliki perusahaan bisa menghasilkan laba menurut (Tandelilin, 2010).

ROA menggambarkan sejauh mana kemampuan asset-asset yang dimiliki perusahaan bisa menghasilkan laba. (Kasmir, 2014)

Mengukur ROA dapat menggunakan rumus sebagai berikut menurut (Kasmir, 2014).

ROA = Earning After Interest and Tax Total Assets

ROE menggambarkan sejauh mana kemampuan perusahaan menghasilkan laba yang bisa diperoleh para pemegang saham (Tandelilin, 2010).

ROE adalah rasio keuangan perusahaan yang digunakan untuk mengukur kemampuan perusahaan untuk memperoleh laba bersih yang tersedia bagi pemegang saham perusahaan menurut (Kasmir, 2014). Rumus ROE sebagai berikut :

\section{ROE = Laba Setelah Pajak Modal Sendiri}

Earning Per Share merupakan salah satu analisis rasio yang berada pada sudut pandang investor atau pemilik perusahaan karena menunjukkan seberapa besar laba yang dihasilkan perusahaan per lembar saham (Tandelilin, 2010).

Earning Per Share (EPS) atau pendapatan perlembar saham adalah bentuk pemberian keuantungan yang diberikan kepada para pemegang saham dari setiap lembar saham yang dimiliki (Fahmi, 2012).

Pengertian laba per lembar saham adalah rasio nilai buku merupakan rasio untuk mengukur keberhasilan manajemen mencapai keuntungan bagi pemegang saham (Kasmir, 2012).

Rumus EPS menurut (Fahmi, 2012) sebagai berikut :

\section{EPS = Laba Setelah Pajak Jumlah Saham Beredar}

"Saham merupakan bagian kepemilikan dalam suatu perusahaan yang dimana setiap lembarnya memberikan hak satu suara kepada pemiliknya" (Bodi, 2014). Harga saham terbagi 3 yaitu nilai buku saham, nilai nominal dan nilai intrinsik menurut (Tandelilin, 2010).

Saham berwujud selembar kertas yang menerangkan bahwa pemilik kertas tersebut adalah pemilik perusahaan yang menerbitkan surat berharga tersebut (Darmadji, 2011).

Harga saham adalah harga saham menentukan kekayaan pemegang saham (Brigham \& Houston, 2010).

Harga saham merupakan harga saham yang terjadi di pasar bursa 
pada saat tertentu yang ditentukan oleh pelaku pasar menurut (Jogiyanto, 2013).

\section{METODE PENELITIAN}

Penelitian ini termasuk jenis penelitian Deskriptif kuantititatif. Metode pengumpulan data dalam penelitian ini yaitu library research dengan cara melihat dari buku, jurnal dan studi literatur yang berhubungan dengan judul penelitian. Sampel penelitian yaitu perusahaan perbankan terdaftar di Bursa Efek Indonesia (BEI) periode 2016-2019.

Data penelitian diperoleh melalui laporan keuangan (Neraca dan Laporan Laba Rugi) perusahaan perbankan yang terdaftar di Bursa Efek Indonesia periode 2016-2019. Perusahaan perbankan yang terpilih berjumlah 8 bank selama 4 tahun. Jumlah sampel sebanyak 32 sampel. Teknik pengambilan sampel yaitu dengan metode purposive sampling.

Kriteria untuk pengambilan sampel dalam penelitian ini sebagai berikut :

1. Perusahaan industri perbankan yang terdaftar berturut-turut di BEI periode 2016-2019.
2. Perusahaan industri perbankan yang telah mempublikasikan laporan keuangan secara lengkap dan berturut-turut dari periode 2016 - 2019.

3. Perusahaan industri perbankan yang memiliki data keuangan sesuai variabel penelitian ROA, ROE dan EPS

4. Perusahaan industri perbankan yang memiliki data yang logis.

Teknik analisis penelitian ini yaitu teknik analisis kuantitatif. Alat analisis data penelitian ini menggunakan SPSS Versi 24 yaitu Uji Asumsi Klasik dan Analisis Regresi Linier Berganda.

\section{HASIL DAN PEMBAHASAN \\ Hasil}

1. Uji Asumsi Klasik

a. Uji Normalitas

Dalam penelitian ini Uji normalitas dengan uji secara analisis statistik KolmogorovSmirnov terlihat pada gambar berikut:

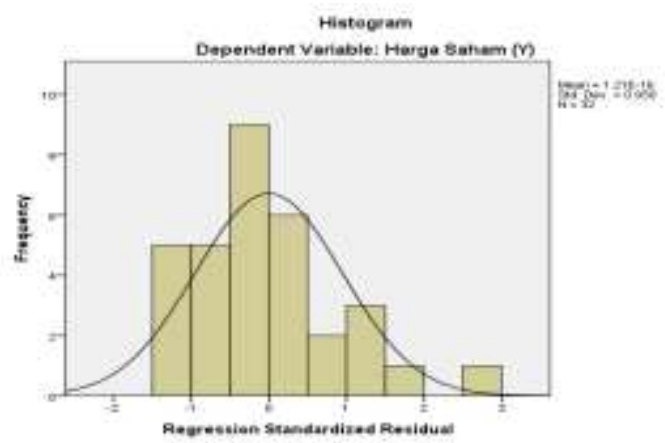

Gambar 1. Uji Normalitas Histogram (Sumber: Diolah dari SPSS, 2020) 
Berdasarkan grafik diatas menunjukkan bahwa gambar garis kurva cenderung simetris (U) maka dapat disimpulkan bahwa data berdistribusi normal.

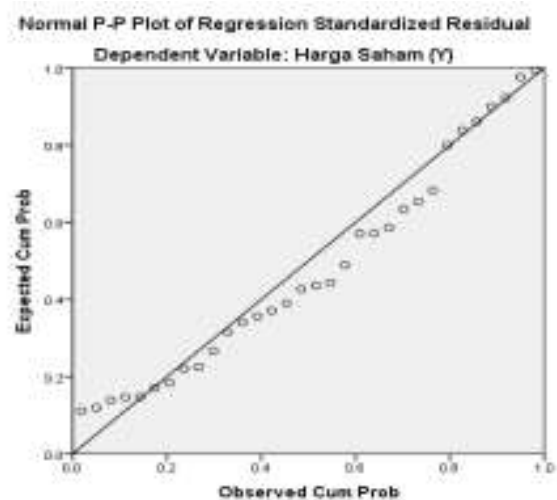

Gambar 2. Probability Plot (Sumber: Diolah dari SPSS, 2020)

Hasil gambar 2 menunjukkan bahwa model berdistribusi normal karena data ploting menggambarkan data sesungguhnya dan mengikuti garis normal. Berdasarkan uji normalitas menggunakan Kormogorov-Smirnov maka kesimpulan dari uji tersebut bahwa model regresi berdistribusi secara normal.

\section{b. Uji Multikolinearitas}

Uji multikolonieritas dapat diketahui dengan tabel dibawah ini.

Tabel 1. Uji Multikolinearitas

\begin{tabular}{|c|c|c|c|c|c|c|c|}
\hline \multicolumn{8}{|c|}{ Coefficients $^{\mathrm{a}}$} \\
\hline \multirow[t]{2}{*}{ Model } & \multicolumn{2}{|c|}{$\begin{array}{c}\text { Unstandardized } \\
\text { Coefficients }\end{array}$} & \multirow{2}{*}{\begin{tabular}{|c|}
$\begin{array}{c}\text { Standardized } \\
\text { Coefficients }\end{array}$ \\
Beta \\
\end{tabular}} & \multirow[t]{2}{*}{$\mathbf{t}$} & \multirow[t]{2}{*}{ Sig. } & \multicolumn{2}{|c|}{$\begin{array}{c}\text { Collinearity } \\
\text { Statistics }\end{array}$} \\
\hline & $\mathbf{B}$ & Std. Error & & & & \begin{tabular}{|l|} 
Tolerance \\
\end{tabular} & VIF \\
\hline 1 (Constant) & -7026.584 & 1350.701 & & -5.202 & .000 & & \\
\hline$\overline{\operatorname{ROA}(\mathrm{X} 1)}$ & 2812.565 & 920.905 & .614 & 3.054 & .005 & .191 & 5.246 \\
\hline$\overline{\mathrm{ROE}(\mathrm{X} 2)}$ & 77.417 & 121.984 & .126 & .635 & .531 & .195 & 5.141 \\
\hline EPS (X3) & 391.547 & 94.634 & .373 & 4.137 & .000 & .949 & 1.053 \\
\hline
\end{tabular}

Sumber: Diolah dari SPSS, 2020

Berdasarkan tabel 1 diatas dapat diketahui nilai VIF untuk variabel ROA, ROE dan PER adalah 5,246 kurang dari 10,00 $(5,246<10,00), \quad$ sementara nilai
Tolerance untuk variabel ROA, ROE dan PER adalah 0,191 lebih besar dari nilai $0,10 \quad(0,191>0,10)$. Berdasarkan uji multikolinearitas dapat disimpulkan bahwa antar 
variabel independent tidak terjadi gejala multikolinearitas dalam model regresi.

\section{c. Uji Heteroskedastisitas}

Untuk menguji sebuah model regresi, apakah terjadi ketidaksamaan varians residual dari satu pengamatan ke pengamatan yang lain merupakan tujuan dari pengujian ini. Apabila terjadi ketidaksamaan varians residual disebut heteroskedastisitas sebaliknya apabila terjadi kesamaan varians residual disebut homokedastisitas.

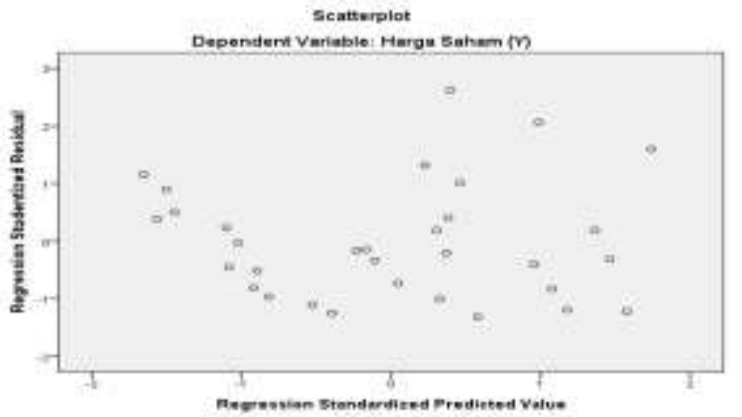

Gambar 3. Scatterplot (Sumber: Diolah dari SPSS, 2020)

Berdasarkan gambar 3 diatas dapat diketahui bahwa titik-titik berada pada sumbu y menyebar diatas dan dibawah dibawah angka 0 ,titik-titik tidak melebar, menyempit dan bergelombang. Maka gambar tersebut memberikan kesimpulan bahwa tidak ada gejala heteroskedastisitas.

\section{d. Uji Autokorelasi}

Untuk menguji apakah model regresi linier terjadi korelasi maka digunakan uji autokorelasi. Regresi yang bebas dari autokorelasi termasuk regresi yang baik. Apabila terjadi korelasi termasuk regresi yang tidak baik, karena ada problem korelasi.

Pengambilan keputusan ada tidaknya autokorelasi pada uji (D-W Test) dapat dilihat pada tabel dibawah ini :

\section{Tabel 2. Uji Autokorelasi}

Model Summary ${ }^{\mathrm{b}}$

\begin{tabular}{|c|c|c|c|c|c|}
\hline Model & R & R Square & $\begin{array}{c}\text { Adjusted R } \\
\text { Square }\end{array}$ & $\begin{array}{c}\text { Std. Error of the } \\
\text { Estimate }\end{array}$ & Durbin-Watson \\
\hline 1 & $.886^{\mathrm{a}}$ & .784 & .761 & 1827.368 & 1.671 \\
\hline
\end{tabular}

a. Predictors: (Constant), EPS (X3), ROE (X2), ROA (X1)

b. Dependent Variable: Harga Saham (Y)

Sumber: Diolah dari SPSS, 2020 
Berdasarkan perhitungan tabel 2 diatas, diperoleh nilai Durbin Watson dari model regresi adalah 1,671 dengan jumlah variabel bebas $(K)=2$ dan jumlah sampel $(N)=16$, maka berdasarkan tabel Durbin Watson diperoleh $\mathrm{dL}=1,2437$ dan $\mathrm{dU}=1,650$. Dari tabel diatas diperoleh nilai DW sebesar 1,671 > dari batas atas (dU) sebesar 1,650 dan < dari 4-dU $(4-1,650=2,350)$. Sesuai dengan pengambilan keputusan uji autokorelasi nilai dU $(1,650)<\mathrm{d}(1,671)<4-\mathrm{dU}(2,350)$, sehingga dapat disimpulkan bahwa tidak terjadi autokorelasi pada data ini.

\section{Analisis Regresi Linear Berganda}

Analisis ini dilakukan untuk meneliti apakah ada dua hubungan sebab akibat antara variabel atau meneliti seberapa besar pengaruh ROA, ROE dan PER terhadap Harga Saham.

a. Uji Regresi

$$
Y=a+b_{1} X_{1}+b_{2} X_{2}+b_{3} X_{3}+e
$$

\section{Keterangan:}

$$
\begin{aligned}
\mathrm{Y} & =\text { Harga Saham } \\
\mathrm{A} & =\text { Bilangan Konstan } \\
\mathrm{X} 1= & \mathrm{ROA} \\
\mathrm{X} 2= & \mathrm{ROE} \\
\mathrm{X} 3= & \text { EPS } \\
\mathrm{e} & =\text { Standar Error } \\
\mathrm{b} 1, \mathrm{~b} 2= & \text { Keofesien Masing- } \\
& \text { Masing Variabel } \\
& \text { Independen }
\end{aligned}
$$

\begin{tabular}{|c|c|c|c|c|c|c|}
\hline & \multirow[t]{2}{*}{ Model } & \multicolumn{2}{|c|}{$\begin{array}{l}\text { Unstandardized } \\
\text { Coefficients }\end{array}$} & \multirow{2}{*}{$\begin{array}{c}\begin{array}{c}\text { Standardized } \\
\text { Coefficients }\end{array} \\
\text { Beta }\end{array}$} & \multirow[t]{2}{*}{$\mathbf{T}$} & \multirow[t]{2}{*}{ Sig. } \\
\hline & & B & Std. Error & & & \\
\hline \multirow[t]{4}{*}{1} & (Constant) & -7026.584 & 1350.701 & & -5.202 & .000 \\
\hline & ROA (X1) & 2812.565 & 920.905 & .614 & 3.054 & .005 \\
\hline & ROE (X2) & 77.417 & 121.984 & .126 & .635 & .531 \\
\hline & EPS (X3) & 391.547 & 94.634 & .373 & 4.137 & .000 \\
\hline
\end{tabular}

Tabel 3. Regresi Linier Berganda

Coefficients $^{\mathrm{a}}$

a. Dependent Variable: Harga Saham (Y)

Sumber: Diolah dari SPSS, 2020

Persamaan regresinya berdasarkan tabel 3 diatas :

$\mathrm{Y}=\mathrm{a}+\mathrm{b} 1 \mathrm{X} 1+\mathrm{b} 2 \mathrm{X} 2+\mathrm{b} 3 \mathrm{X} 3+\mathrm{e}$

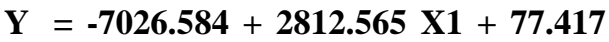

$\mathrm{X} 2+391.547 \mathrm{X3}+\mathrm{e}$

Penjabaran dari Persamaan regresi diatas sebagai berikut :

1. Nilai konstanta sebesar 7026.584, artinya jika ROA (X1) dan ROE (X2) dan EPS (X3) nilainya adalah 0 , maka Harga Saham (Y) nilainya sebesar 7026.584 .

2. Koefesien regresi variabel ROA (X1) sebesar 2812.565, artinya jika variabel independen lain nilainya tetap dan ROA 
mengalami kenaikan 1 satuan, maka Harga Saham (Y) akan mengalami kenaikan sebesar 2812.565 .

3. Koefesien regresi variabel ROE (X2) sebesar 77.417, artinya jika variabel independen lain nilainya tetap dan ROE mengalami kenaikan 1 satuan, maka akan meningkatkan Harga Saham (Y) sebesar 77.417.

4. Koefesien regresi variabel EPS (X3) sebesar 391.547, artinya jika variabel independen lain nilainya tetap dan PER mengalami kenaikan 1 satuan, maka akan meningkatkan Harga Saham (Y) sebesar 391.547.

\section{b. Koefisien Determinasi $\left(\mathbf{R}^{2}\right)$}

Analisis ini digunakan untuk mengetahui seberapa besar pengaruh variabel independen yaitu ROA, ROE dan PER terhadap variabel dependen yaitu Harga Saham.

Tabel 4. Koefesien Determinasi

Model Summary ${ }^{\text {b }}$

\begin{tabular}{|c|c|c|c|l|}
\hline Model & \multicolumn{1}{|c|}{ R } & \multicolumn{1}{c|}{ R Square } & Adjusted R Square & Std. Error of the Estimate \\
\hline 1 & $.886^{\mathrm{a}}$ & .784 & .761 & 1827.368 \\
\hline
\end{tabular}

a. Predictors: (Constant), DER (X3), ROE (X2), ROA (X1)

b. Dependent Variable: Harga Saham (Y)

Sumber: Diolah dari SPSS, 2020

Nilai koefisien determinasi Adjusted $R$ Square sebesar 0,761 atau $76,1 \%$ memiliki arti bahwa variabel ROA (X1) dan ROE (X2) dan EPS (X3) secara simultan berpengaruh terhadap variabel Harga Saham (Y) sebesar 76,1\% dan sisanya sebesar $23,9 \%$ dipengaruhi oleh faktor lain diluar penelitian ini.

\section{c. Uji Hipotesis (Uji T) Parsial}

Uji $\mathrm{t}$ (Parsial) menggunakan dasar pengambilan keputusan adalah sebagai berikut:

Berdasarkan nilai signifikansi (Sig.)

- Nilai probalitas signifikansi < 0,05, maka hipotesis diterima.

Tabel 5. Uji Parsial (t)

Coefficients $^{\mathrm{a}}$

\begin{tabular}{|c|c|c|c|c|c|c|}
\hline & \multirow[b]{2}{*}{ Model } & \multicolumn{2}{|c|}{$\begin{array}{c}\text { Unstandardized } \\
\text { Coefficients }\end{array}$} & \multirow{2}{*}{$\begin{array}{c}\begin{array}{c}\text { Standardized } \\
\text { Coefficients }\end{array} \\
\text { Beta }\end{array}$} & \multirow[b]{2}{*}{$\mathbf{T}$} & \multirow[b]{2}{*}{ Sig. } \\
\hline & & B & Std. Error & & & \\
\hline \multirow[t]{4}{*}{1} & (Constant) & -7026.584 & 1350.701 & & -5.202 & .000 \\
\hline & $\mathrm{ROA}(\mathrm{X} 1)$ & 2812.565 & 920.905 & .614 & 3.054 & .005 \\
\hline & ROE (X2) & 77.417 & 121.984 & .126 & .635 & .531 \\
\hline & EPS (X3) & 391.547 & 94.634 & .373 & 4.137 & .000 \\
\hline
\end{tabular}

a. Dependent Variable: Harga Saham (Y)

Sumber: Diolah dari SPSS, 2020 
Berdasarkan nilai signifikansi (Sig.)

1. Pada tabel 5 memperlihatkan hasil pengujian secara parsial antara variabel ROA terhadap Harga Saham. Nilai signifikansi (Sig.) berdasarkan tabel 5 sebesar 0,005. Karena nilai Sig. 0,005 < probabilitas 0,05 , kesimpulannya bahwa H1 diterima artinya variabel ROA (X1) memiliki pengaruh positif dan signifikan terhadap variabel Harga Saham (Y).

2. Pada tabel 5 memperlihatkan hasil pengujian secara parsial antara variabel ROE terhadap Harga Saham. Diperoleh nilai signifikansi (Sig.) sebesar 0,531 berdasarkan tabel diatas. Karena nilai Sig. 0,531> probabilitas 0,05, artinya bahwa $\mathrm{H} 2$ ditolak, artinya variabel ROE (X2) tidak berpengaruh terhadap variabel Harga Saham (Y).

3. Pada tabel 5 memperlihatkan hasil pengujian secara parsial antara variabel PER terhadap Harga Saham. Nilai signifikansi
(Sig.) sebesar 0,000 pada table tersebut. Nilai Sig. $0,000<$ probabilitas 0,05 , menunjukkan bahwa H3 diterima, artinya variabel EPS (X3) berpengaruh positif dan signifikan terhadap variabel Harga Saham (Y).

\section{d. Uji F (Simultan)}

Menurut (Ghozali, 2013) Jika nilai sig $<0,05$ maka artinya variabel independent (X) secara simultan berpengaruh terhadap variabel dependent Y. Uji F (Simultan) digunakan untuk menguji hipotesis ini sebagai berikut:

Berdasarkan nilai signifikansi (Sig.)

- Jika nilai signifikasi <0,05 maka variabel independen (bebas) berpengaruh signifikan secara bersamasama terhadap variabel dependen (terikat).

- Jika nilai signifikasi >0,05 maka variabel independen (bebas) tidak berpengaruh signifikan secara bersamasama terhadap variabel dependen (terikat).

Tabel 6. Uji Simultan (F)

ANOVA $^{\mathrm{a}}$

\begin{tabular}{|c|l|r|r|r|r|r|}
\hline \multicolumn{2}{|c|}{ Model } & \multicolumn{1}{c|}{ Sum of Squares } & \multicolumn{1}{c|}{ df } & Mean Square & \multicolumn{1}{c|}{ F } & \multicolumn{1}{c|}{ Sig. } \\
\hline \multirow{3}{*}{1} & Regression & 340149688.200 & 3 & 113383229.400 & 33.954 & $.000^{\mathrm{b}}$ \\
\cline { 2 - 7 } & Residual & 93499694.630 & 28 & 3339274.808 & & \\
\cline { 2 - 8 } & Total & 433649382.900 & 31 & & & \\
\hline
\end{tabular}

a. Dependent Variable: Harga Saham (Y)

b. Predictors: (Constant), PER (X3), ROE (X2), ROA (X1)

Sumber: Diolah dari SPSS, 2020

Tabel 6 menunjukkan hasil pengujian secara simultan antara variabel ROA (X1), ROE (X2) dan EPS (X3) terhadap Harga Saham 
(Y). Tabel tersebut memiliki nilai signifikansi (Sig.) sebesar 0,000. Nilai Sig. 0,000 < probabilitas 0,05, sehingga dapat disimpulkan bahwa $\mathrm{H} 4$ diterima, artinya variabel ROA (X1), ROE (X2) dan EPS (X3) secara simultan berpengaruh terhadap variabel Harga Saham (Y).

\section{Pembahasan}

\section{Pengaruh Variabel ROA (X1) Terhadap Variabel Harga Saham (Y)}

Berdasarkan hasil uji secara parsial variabel ROA (X1) diperoleh bahwa nilai dari signifikansi (Sig.) sebesar 0,005. Karena nilai Sig. $0,005<$ probabilitas 0,05 , sehingga dapat disimpulkan bahwa $\mathrm{H} 1$ diterima, artinya variabel ROA (X1) berpengaruh terhadap variabel Harga Saham (Y).

Hasil dari penelitian ini sejalan dengan peneliti sebelumnya (Anita, 2018) hasil dari penelitiannya memberikan kesimpulan bahwa secara parsial variabel ROA berpengaruh secara signifikan terhadap harga saham pada perusahaan makanan dan minuman yang terdaftar di BEI periode 20142017.

Hasil dari penelitian ini tidak sejalan dengan hasil penelitian (Al Umar, 2020), menyatakan dalam penelitiannya bahwa variabel ROA tidak berpengaruh secara signifikan terhadap harga saham. Hasil penelitian (Sorongan, 2019), menyimpulkan bahwa ROA tidak memiliki pengaruh yang signifikan terhadap harga saham.

\section{Pengaruh Variabel ROE (X2) Terhadap Variabel Harga Saham (Y)}

Berdasarkan Hasil uji Variabel ROE (X2) secara parsial dengan nilai signifikansi (Sig.) sebesar 0,531. Karena nilai Sig. 0,531 > probabilitas 0,05 sehingga dapat disimpulkan bahwa H2 ditolak, artinya variabel ROE (X2) tidak berpengaruh terhadap variabel Harga Saham (Y).

Hasil dari penelitian ini sejalan dengan peneliti sebelumnya (Al Umar, 2020), menyimpulkan bahwa ROE tidak berpengaruh secara signifikan terhadap harga saham.

Peneliti (Efendi \& Ngatno, 2018), memberikan kesimpulan dalam penelitiannya bahwa variabel ROA tidak berpengaruh secara signifikan terhadap harga saham perusahaan sub sektor tekstil dan garmen terdaftar di BEI.

Hasil dari penelitian ini tidak sejalan dengan hasil penelitian (Rahmadewi \& Abudanti, 2018), menyimpulkan dalam penelitiannya bahwa variabel ROE berpengaruh negatif dan signifikan terhadap harga saham pada perusahaan di Bursa Efek Indonesia.

Menurut (Sorongan, 2019), menyatakan bahwa ROE mempunyai pengaruh yang signifikan terhadap harga saham perusahaan otomotif terdaftar di BEI.

\section{Pengaruh Variabel EPS (X3) Terhadap Variabel Harga Saham (Y)}


Dari hasil pengujian secara parsial variabel EPS (X3) diperoleh nilai signifikansi (Sig.) sebesar 0,000. Dari hasil nilai Sig. 0,000 < probabilitas 0,05 sehingga hasil hipotesis H3 diterima, artinya variabel EPS (X3) berpengaruh secara signifikan terhadap variabel Harga Saham (Y).

Hasil dari penelitian ini sejalan dengan peneliti sebelumnya (Al Umar, 2020), menyimpulkan bahwa EPS berpengaruh secara signifikan terhadap harga saham. Hasil penelitian dari (Sorongan, 2019), memberikan kesimpulan dalam penelitiannya bahwa EPS memiliki pengaruh signifikan terhadap harga saham perusahaan otomotif yang terdaftar di BEI.

Menurut (Efendi \& Ngatno, 2018), menyatakan bahwa EPS berpengaruh secara signifikan terhadap harga saham perusahaan sub sektor tekstil dan garmen yang terdaftar di BEI.

Hasil dari penelitian ini tidak sejalan dengan peneliti sebelumnya (Rahmadewi \& Abudanti, 2018), menyimpulkan dalam penelitiannya bahwa terdapat hubungan negatif dan tidak signifikan antara variabel EPS terhadap harga saham pada perusahaan di Bursa Efek Indonesia.

Menurut (Anita, 2018), menyatakan bahwa secara parsial variabel EPS berpengaruh negatif dan tidak signifikan terhadap harga saham pada perusahaan makanan dan minuman yang terdaftar di BEI.

\section{Pengaruh Variabel ROA (X1),Variabel ROE (X2) dan EPS (X3) Terhadap Variabel Harga Saham (Y)}

Pengaruh variabel independen yaitu ROA, ROE dan EPS terhadap Harga Saham secara simultan dengan nilai signifikansi (Sig.) hasil uji ANOVA atau uji $F$ secara simultan sebesar 0,000. Karena nilai Sig. $0,000<$ probabilitas 0,05 maka dapat disimpulkan bahwa $\mathrm{H} 4$ diterima. Artinya bahwa variabel ROA, ROE dan EPS secara simultan berpengaruh signifikan terhadap variabel Harga Saham.

Hasil dari penelitian ini sejalan dengan peneliti sebelumnya (Al Umar, 2020), menyatakan dalam penelitiannya bahwa ROA, ROE dan EPS secara simultan berpengaruh secara signifikan terhadap harga saham.

Hasil penelitian oleh (Sorongan, 2019), menyimpulkan bahwa ROA tidak memiliki pengaruh signifikan terhadap harga saham sedangkan ROE dan EPS memiliki pengaruh signifikan terhadap harga saham perusahaan otomotif yang terdaftar di BEI.

\section{KESIMPULAN}

Kesimpulan dari penelitian ini sebagai berikut:

1. Variabel ROA mempunyai pengaruh positif dan signifikan terhadap variabel harga saham perusahaan perbankan periode 2016-2019.

2. Variabel ROE mempunyai pengaruh positif dan signifikan terhadap variabel harga saham 
perusahaan perbankan periode 2016-2019.

3. Variabel EPS mempunyai pengaruh positif dan signifikan terhadap variabel harga saham perusahaan perbankan periode 2016-2019.

4. Variabel ROA, ROE dan EPS berpengaruh secara positif dan signifikan terhadap variabel harga saham perusahaan perbankan periode 2016-2019.

5. Peneliti selanjutnya disarankan agar menambah jumlah sampel, menambah rasio keuangan dan mencari variabel lain yang mempengaruhi harga saham.

\section{DAFTAR PUSTAKA}

Al Umar, AUA. (2018). Analisis Pengaruh ROA, ROE, EPS Terhadap Harga Saham. Jurnal Akuntansi dan Perpajakan. Volume 4 No.1, 30-36

https://ejournal.unitomo.ac.id/index. php/akuntansi/article/view/305 1

Astuti, ODD. (2018). Pengaruh ROA, EPS dan NPM Terhadap Harga Saham Pada Perusahaan Makanan dan Minuman Yang Terdaftar di Bursa Efek Indonesia (BEI) Periode 20142017. Jurnal Ekonomi Manajemen. Volume 4 No.2, 134-142

http://jurnal.unsil.ac.id/index.php/je $\mathrm{m} /$ article/download/703/454

Ani,Trianasari \& Cipta. (2019). Pengaruh EPS, ROE Serta EPS Terhadap Harga Saham Sektor Farmasi Yang Terdaftar di BEI. Jurnal Manajemen
Bisma. Volume 5 No.2, 148157

Brigham \& Houston. (2010). Dasardasar Manajemen Keuangan Buku 1 (Edisi 11). Jakarta: Salemba Empat

Bodi, Kane dan Marcus. (2014). Manajemen Portofolio dan Investasi (Investment). Edisi 9 Jilid 2. Jakarta: Salemba

Darmadji, T.D. (2011). Pasar Modal di Indonesia. Jakarta : Salemba Empat

Efendi, FM \& Ngatno (2018). Pengaruh ROA Terhadap Harga Saham dengan EPS sebagai Enterpening (Studi Kasus pada Perusahaan Sub Sektor Tekstil dan Garmen Yang Terdaftar di Bursa Efek Indonesia Periode 2013-2016). Jurnal Administrasi Bisnis. Volume 7 No.1, 1-9

Egam, Illat \& Pangerapan. (2017). Pengaruh ROA, ROE, NPM dan EPS Terhadap Harga Saham Perusahaan yang Tergabung Dalam Indeks LQ45 DI Bursa Efek Indonesia Tahun 2013-2015. Jurnal EMBA. Volume 5 No.1, 105114.

https://ejournal.unsrat.ac.id/index.ph p/emba/article/view/15455/149 98

Fadila,R \& Saifi,M. (2018). Pengaruh EPS, ROE dan NPM Terhadap Harga Penutupan Saham (Studi Pada Perusahaan Perbankan Yang Terdaftar di Bursa Efek Indonesia Periode 2014-2016. Jurnal Administrasi Bisnis. Volume 61 No.3, 154-162 
http://administrasibisnis.studentjourn al.ub.ac.id/index.php/jab/article /view/2609/3003

Fahmi, Irham. (2013). Pengantar Manajemen Keuangan. Bandung : Alfabeta

Ghozali, Imam. 2013. Aplikasi Analisis Multivariate dengan Program SPSS. Edisi Ketujuh. Semarang: Badan Penerbit Universitas Diponegoro.

Husna, Nailal. (2016). Analisis Pengaruh Kinerja Keuangan Terhadap Harga Saham Pada Perusahaan Perbankan. Jurnal Apresiasi Ekonomi. Volume 4 No.2, 151-156.

Jogiyanto. (2013). Teori Portofolio dan Analisis Investasi. Edisi Ketiga. Yogyakarta: BPFE UGM

Kasmir. (2014). Analisis Laporan Keuangan. Depok: Rajawali Pers

Kasmir. (2010). Pengantar Manajemen Keuangan. Jakarta: Kencana

Munawir. (2014). Analisa Laporan keuangan. Yogyakarta: Liberty

Rahmadewi, PW \& Abudanti, N. (2018). Pengaruh EPS, PER, CR dan ROE Terhadap Harga Saham di Bursa Efek Indonesia. E-Jurnal Manajemen Unud. Volume 7 No.4, 2106-2133

https://ocs.unud.ac.id/index.php/Man ajemen/article/download/37167 123263

Sari, LD. (2016). Pengaruh Profitabilitas Terhadap Harga Saham Pada Bank Milik Pemerintah (BUMN) Yang Terdaftar di Bursa Efek Indonesia (BEI) Periode 2007-
2014. JOM FISIP. Volume 3 No.2, 1-13

Sari, DI. (2020). Pengaruh Quick Ratio, Total Asset Turnover \& Return On Ivestment. Balance. Volume 5 No.2, 123 -134

Sorongan, FA. (2019). Pengaruh ROA, ROE, EPS Terhadap Harga Saham Pada Perusahaan Otomotif Yang Terdaftar di BEI. Jurnal Ilmiah Manajemen Bisnis dan Inovasi. Universitas Sam Ratulangi. Volume 6 No. 2, 106-113

https://ejournal.unsrat.ac.id/index.ph p/jmbi/article/view/26287/2625 7

Tandelilin, Eduardus.(2010). Analisis Investasi dan Manajemen Portofolio. Edisi Pertama. Yogyakarta: BPFEYogyakarta.

Triawan, R \& Shofawati,A. (2018). Pengaruh ROA, ROE, NPMN dan EPS Terhadap Harga Saham Perusahaan Di Jakarta Islamic Index (JII) Periode 2011-2015. Jurnal Ekonomi Syariah Teori dan Terapan. Volume 5 No.7, 541-555

https://www.neliti.com/id/publicatio ns/315031/pengaruh-roa-roenpm-dan-eps-terhadap-hargasaham-perusahaan-di-jakartaislamic 